\title{
Growth and Physiological Responses of Landscape Plants to Saline Water Irrigation: A Review
}

\author{
Genhua Niu' \\ Texas AgriLife Research and Extension Center at El Paso, Texas A\&M University System, \\ 1380 A\&M Circle, El Paso, TX 79927 \\ Raul I. Cabrera \\ Texas AgriLife Research and Extension Center at Dallas, Texas A\&M University System, \\ 17360 Coit Road, Dallas, TX 75252
}

Additional index words. landscape irrigation, salinity tolerance, water reuse

\begin{abstract}
Water shortages and poor water quality are critical issues in many areas of the world. With rapid increases in population and shortage of water supplies in urban areas, use of alternative water sources such as municipal reclaimed water and other sources of non-potable waters for irrigating landscapes is inevitable. A potential concern is the elevated salt levels in these alternative waters. This article briefly summarizes general information regarding alternative water sources and general responses of landscape plants to salinity stress. Methodology of screening and evaluating salt tolerance of landscape plants are discussed. Recent research results on salt tolerance of landscape plants and their physiological responses to salinity stress are reviewed. Like agricultural crops, a wide range of salt tolerance among landscape plants has been found. In addition to plant species, dominant salt type, substrate, irrigation method and management, and environmental conditions also affect plant responses to salinity stress. A number of mechanisms of salinity tolerance have been observed among landscape species, including restriction of ion uptake, selective ion uptake, and tolerance to high internal concentrations of sodium and/or chloride.
\end{abstract}

With rapidly increasing populations and industrialization in many parts of the world, the demand for fresh water supply is increasing but the availability of fresh water is diminishing. Seeking alternative water sources for irrigating field crops and landscapes is an option to save fresh water for other purposes. The availability of reclaimed water (treated municipal wastewater) may increase with urban population growth (Qian et al., 2005). Many municipalities in the southwest have encouraged the use of reclaimed water for landscape irrigation, because municipal water consumption increases two- to twofold in summer months compared with the winter season (Kjelgren et al., 2000). The increased water use is largely for landscape irrigation. Therefore, irrigating landscapes with reclaimed water can conserve tremendous amounts of fresh water. Reclaimed water and other nonpotable waters have been used for decades for irrigating field crops and landscapes such as golf courses, landscapes, and parks in many areas of the United States (Dobrowolski et al., 2008; Morgan et al., 2008) and other countries (Pasternak and Malach, 1994; Safi et al., 2007; Tanwar, 2003). Reclaimed water contains some nutrients essential for plant growth and therefore it may be possible to reduce fertilizer application when reclaimed water is used. A potential problem of using reclaimed water is elevated salt levels, which are detrimental to sensitive plants if not managed properly.

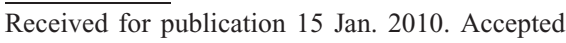
for publication 22 Feb. 2010.

Part of a colloquium (The Efficient Use of Alternative Water and Traditional Irrigation Sources in Horticulture) presented 25 July 2009 at ASHS-2009, St. Louis, MO; sponsored by the Water Utilization and Management (WUM) Working Group.

${ }^{1}$ To whom reprint requests should be addressed; e-mail gniu@ag.tamu.edu.
}

Therefore, identifying salt-sensitive plant species and categorizing salt tolerance of commonly used landscape plants may aid the selection of appropriate species for landscapes where alternative sources of water are used for irrigation.

\section{GENERAL INFORMATION ON ALTERNATIVE WATER SOURCES}

The types of available alternative or nonpotable water sources vary with regions or even locations. Generally, municipal reclaimed water is the main alternative water. In some places, groundwater or sallow aquifer saline water and agricultural drainage water are available (Boland, 2008; Duncan et al., 2009). The salinity and composition of these alternative waters vary with locations and sources.

Reclaimed water is defined as domestic or municipal wastewater that has received secondary treatment. Reclaimed water is also improperly called by other terms, including recycled water, urban wastewater, urban water reuse, and urban effluent (Duncan et al., 2009). These latter terms actually denote urban water sources that have not been treated and include storm water and rain water. Reclaimed water is also different from gray water, which is untreated, non-toilet, and household water, including water from sinks, showers, and baths. The salinity of reclaimed water measured as electrical conductivity, which varies depending on the water source and treatment processes, ranged from 1.0 to $1.9 \mathrm{dS} \cdot \mathrm{m}^{-1}$ (Schuch, 2005; Wu et al., 2001). The chemical composition in reclaimed water varies with treatment processes, source waters, location, and time of year. Although some water reclamation treatment facilities offer periodic laboratory test results, the data are often incomplete for assessing irrigation quality because they are oriented to the "human impact factor" and less to the performance of plants that would be irrigated (Duncan et al., 2009). The main chemical compounds of horticultural interest in reclaimed water, after going through all treatment processes, are nitrogen, phosphorus, potassium, calcium, magnesium $(\mathrm{Mg})$, sodium $(\mathrm{Na})$, chloride $(\mathrm{Cl})$, bicarbonate, and sulfate $\left(\mathrm{SO}_{4}\right)$ (Duncan et al., 2009; Farnham et al., 1985; Wu et al., 2001).

\section{METHODS OF SCREENING SALT TOLERANCE FOR LANDSCAPE PLANTS}

Greenhouse studies. Compared with field trials, greenhouse studies for screening salt tolerance are less labor-intensive, less costly, and the environmental conditions can be more easily controlled. Salt treatments in greenhouse studies are usually created by adding salts to irrigation water to mimic a composition of a target saline water source or saline soil. A large number of salinity studies have used $\mathrm{NaCl}$ as the sole salinizing agent (Cassaniti et al., 2009; Eom et al., 2007; Fostad and Pedersen, 2000; Marosz, 2004; Wahome, 2003; Wu et al., 2001). However, composition of salts in water and salt-affected soils varies throughout the world (Carter and Grieve, 2006; Grattan and Grieve, 1999). Saline solutions with a single salt may result in misleading and erroneous interpretations about plant response to salinity (Carter and Grieve, 2006; Grattan and Grieve, 1999). In our studies, $\mathrm{NaCl}+\mathrm{CaCl}_{2}(2: 1 \mathrm{M}$ ratio) or $\mathrm{NaCl}+$ $\mathrm{CaCl}_{2}+\mathrm{MgSO}_{4}$ (87:8:5 by weight) have been added to tap water or nutrient solutions to mimic the major ion composition of local poor-quality reclaimed waters. A wide range of salinity levels, depending on the estimated salt tolerance of selected species being tested, are prepared to distinguish the differences in plant response to increasing salinity. Even 
when salinity levels of irrigation water are kept the same, the maintenance of constant root zone salinity levels is difficult, and equally challenging is its measurement because of the strong influence of soil moisture content (Marosz, 2004; Tanji, 2002). The concentration of dissolved salts does not change in direct proportion to changes in soil moisture content as a result of solubility, cation exchange, and ion association issues.

Salinity is a dynamic property in the root zone resulting from evapoconcentration of the soil solution, water extraction, selective plant uptake from plant roots, and replenishment by irrigation or rainfall (Tanji, 2002). Salt accumulation in substrates is also influenced by plant taxa and genotypes, substrate physicalchemical properties, plant water use, irrigation frequency, and drainage and/or leaching fraction (Bernstein et al., 2006; Niu and Rodriguez, 2006a, 2006b). To prevent salt accumulation, increasing leaching fraction and using porous, well-drained substrates are effective approaches. However, high leaching fraction leads to low irrigation efficiencies (Niu et al., 2007b).

Outdoor container and field studies. Environmental conditions such as temperature, light intensity, humidity, and wind speed can considerably affect plant response to salinity (Fox et al., 2005; Niu et al., 2007a; Zollinger et al., 2007). Therefore, salt tolerance of plants from greenhouse studies provides a relative order of salt tolerance among tested plant species. The absolute salt tolerance in outdoor conditions for landscape plants can be determined on a limited number of plants with known salt tolerance under greenhouse environment. For field studies, soils will be salinized after a salt tolerance study and thus will require replacement before reutilization in subsequent experiments in the same field. In our research, raised beds have been used and soils in the beds are replaced before each experiment (Niu et al., 2007a). Treatments were created similarly to greenhouse studies by adding salts at various ratios to irrigation water to create various salinity levels. Like greenhouse container studies, salt accumulation in the field varied among beds and locations within the same bed as a result of differences in water use of the plants and microenvironment. Outdoor studies using containers can provide outdoor environmental conditions while eliminating the variation among adjacent plots and easing the control and disposal of salinized substrates or soils. In reality, selection of method for screening salt tolerance often depends on target plant species, seasons, and availability of resources.

\section{GENERAL RESPONSES OF LANDSCAPE PLANTS TO SALINITY}

Salt tolerance of a plant is defined as the ability to withstand the effects of high salinity without significant adverse effects such as growth or yield reduction or foliar salt damage (Grieve et al., 2008). Salinity reduces the ability of plants to take up water, and this quickly causes reductions in growth rate along with a suite of metabolic changes identical to those caused by water stress (Marschner, 1995; Munns, 2002). For landscape plants, the typical symptoms of initial salt injury are stunted growth and foliar damage, including leaf necrosis, marginal leaf burn, and premature leaf drop (Bernstein et al., 1972). As salt stress becomes severe, leaves are generally negatively impacted, resulting in fewer green leaves. For flowering woody shrubs and trees, buds may fail to open or grow and branches may die in salt-stressed shrubs and trees (Azza Mazher et al., 2007). Salt injury symptoms are more evident under hot, dry, and windy conditions than in a cool, humid environment (Fox et al., 2005; Niu et al., 2007a; Wu et al., 2001). Salt tolerance of a plant varies largely with species or even cultivar within a species (Cabrera, 2009; Niu et al., 2007a). The actual response of a plant to salinity is often affected by climate conditions, type of substrate or soil, irrigation management, and plant growth stage. For each salinity level, it is possible to select a number of landscape plants whose aesthetic values are not or are only slightly affected (Bernstein et al., 1972). Obviously, as salinity levels increase, the number of plants that can tolerate the salt stress becomes smaller.

High salinity induces a series of metabolic dysfunctions in landscape plants, including absorption of excessive minerals, nutrient imbalance, photosynthesis inhibition, enzymatic activity, protein and nucleic metabolism, and respiration (Azza Mazher et al., 2007; Marschner, 1995; Munns and Tester, 2008). The extent of adverse impact of salinity on the previously mentioned physiological processes depends on salinity levels and exposure period.

\section{QUANTIFYING GROWTH, PHYSIOLOGICAL AND AESTHETIC RESPONSES OF LANDSCAPE PLANTS TO SALINITY}

Depending on species or genotype, growth can be quantified non-destructively by recording plant height and/or canopy size periodically. All parts of a plant, including leaves, stems, roots, and fruits, may be reduced in size under saline conditions. Usually, growth reduction in shoots is greater than roots (Munns, 2002; Shannon et al., 1994). For agricultural crop plants, salt tolerance is often assessed based on growth or yield reduction of specific plant parts such as seeds, roots, fruits, or leaves (Maas, 1990; Pasternak and Malach, 1994). However, for landscape plants, aesthetic value is more important than growth rate (Bernstein et al., 1972). Therefore, visual quality, although it can be highly subjective, is an important parameter for assessing salt tolerance of landscape plants (Devitt et al., 2005; Fox et al., 2005; Niu and Rodriguez, 2006a, 2006b; Niu et al., 2007a; Zollinger et al., 2007). Dry matter accumulation and/or relative growth rate are commonly used to evaluate salt tolerance of plants, but this parameter is not available until plants are harvested destructively. The timing when significant differences in foliar damage symptoms appear is another parameter used for the assessment of plant salt tolerance. The earlier the salt injury is exhibited in a plant, the less is its tolerance to salinity.

In addition to these visible changes reflected in plant growth/size and foliar damage, plants also respond to salinity internally, expressed in changes in physiological and metabolic processes. To quantify the physiological responses to salinity, photosynthesis, leaf conductance, chlorophyll fluorescence, chlorophyll content, ion uptake, and accumulation in tissues are typically measured (Cabrera, 2003; Eom et al., 2007; Niu and Rodriguez, 2006a; Quist and Williams, 1999; Wu et al., 2001; Zollinger et al., 2007; Zribi et al., 2009).

Ion uptake. Plant adaptations to salinity are of three distinct types: osmotic stress tolerance, $\mathrm{Na}$ or $\mathrm{Cl}$ exclusion, and the tolerance of tissue to accumulated $\mathrm{Na}$ or $\mathrm{Cl}$ (Munns and Tester, 2008). Salt-tolerant genotypes usually have the ability to restrict $\mathrm{Na}$ or $\mathrm{Cl}$ transport to shoots. Some tolerant genotypes can tolerate high internal $\mathrm{Na}$ or $\mathrm{Cl}$ concentrations. Ion uptake depends on species or genotype, salinity level, and the chemical composition of the soil solution (Grattan and Grieve, 1999; Niu and Rodriguez, 2008).

Niu and Rodriguez (2006a) studied differences in overall salt tolerance and $\mathrm{Na}$ or $\mathrm{Cl}$ tolerance among eight herbaceous species irrigated with saline solutions at four salinity levels. Four species died by the middle of the 12 -week experiment. Among the surviving four species, the ion accumulation in shoots and roots differed (Fig. 1). Both $\mathrm{Na}$ and $\mathrm{Cl}$ in shoots and roots generally increased with salinity of irrigation water in all species but were different among species. For example, Gazania rigen had the highest Na concentration in shoots [39 $\mathrm{mg} \cdot \mathrm{g}^{-1}$ dry weight (DW)] but Delosperma cooperi had the highest $\mathrm{Na}$ concentration in roots $\left(22 \mathrm{mg} \cdot \mathrm{g}^{-1} \mathrm{DW}\right)$. Shoot $\mathrm{Cl}$ was highest in $D$. cooperi and $G$. rigen and even in the control plants. The $\mathrm{Cl}$ concentration was five to 10 times higher in $D$. cooperi and $G$. rigen than the other two species in all treatments. Regardless of the high $\mathrm{Na}$ or $\mathrm{Cl}$ concentrations, no visual salt injury was observed in $G$. rigen and D. cooperi, indicating that these two species were tolerant to high internal $\mathrm{Na}$ or $\mathrm{Cl}$ concentrations. Compared with $G$. rigen, D. cooperi had a higher ability to exclude $\mathrm{Na}$ from shoots, which is an important mechanism of salt tolerance. In a 15-week salinity study, significant differences in ion accumulation were found between two azalea (Rhododendron) hybrids (Cabrera, 2003). The hybrid 'Delaware Valley White', which was more negatively affected by salinity stress (both in growth and quality), accumulated exceedingly higher levels of $\mathrm{Cl}$ and $\mathrm{Na}$ (up to $3.33 \%$ and 5.65 $\mathrm{mg} \cdot \mathrm{g}^{-1} \mathrm{DW}$, respectively) than in the more salt-tolerant 'Red Hershey' (up to $1.31 \%$ and $0.46 \mathrm{mg} \cdot \mathrm{g}^{-1} \mathrm{DW}$, respectively). Another 15 -week salinity study with crape myrtles (Lagerstroemia spp. L.) showed differences in $\mathrm{Na}$ and $\mathrm{Cl}$ accumulation in leaf tissues being lower in those cultivars that were deemed 


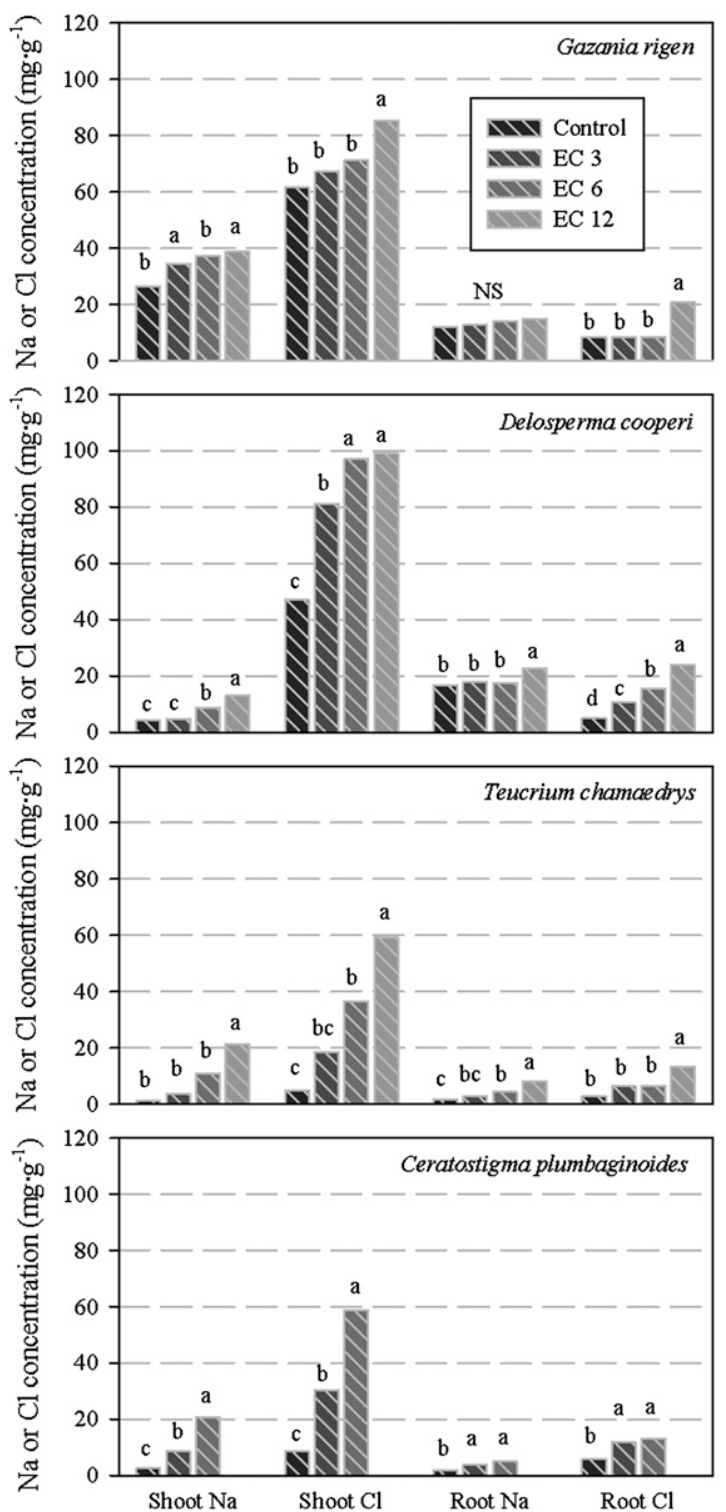

Fig. 1. Shoot and root ion concentrations of Gazania rigens, Delosperma cooperi, Teucrium chamaedrys, and Ceratostigma plumbaginoides at the end of a 12-week experiment as affected by irrigation water salinity [electrical conductivity (EC)]. Control, EC 3, EC 6, and EC 12 represent EC of 0.8, 3.2, 6.4, and $12 \mathrm{dS} \cdot \mathrm{m}^{-1}$, respectively. Means (bars) followed by the same letters are not significantly different tested by Student-Newman-Keuls multiple comparison at $P=0.05$. Note: Ceratostigma plumbaginoides plants did not survive at EC $12 \mathrm{dS} \cdot \mathrm{m}^{-1}$.

more salt-tolerant on the basis of lesser foliar salt damage (Cabrera, 2009).

Salt composition affects the response of landscape plants to salinity. Growth and ion uptake of four rose rootstocks responded to salinity and dominant salt type differently (Niu and Rodriguez, 2008). Rosa $\times$ fortuniana was the most tolerant rootstock when irrigated with a saline solution dominated by sulfate followed by $R$. 'Dr. Huey', $R$. multiflora, and $R$. odorata in descending order. However, $R$. $\times$ fortuniana was the least tolerant rootstock when chloride was dominant in the saline solutions, $R$. odorata was the second least tolerant, and 'Dr. Huey' was the most tolerant. Rosa $\times$ fortuniana and 'Dr. Huey' had a higher restriction ability of $\mathrm{Na}$ uptake than the other two rootstocks.

Leaf gas exchange. The most dramatic and readily measurable whole plant response to salinity is a decrease in stomatal aperture (Munns and Tester, 2008). Rates of photosynthesis per unit leaf area in salt-treated plants are often unchanged, although stomatal conductance $\left(g_{\mathrm{S}}\right)$ is reduced (James et al., 2002). Net photosynthetic rate of four rose rootstocks (Rosa $\times$ fortuniana, R. multiflora, $R$. odorata, and $R$. hybrida 'Dr. Huey'), which were irrigated with saline solutions up to $8.0 \mathrm{dS} \cdot \mathrm{m}^{-1}$, were unaffected (Niu, unpublished data), possibly because the healthy, young leaves were selected. The effect of salinity on photosynthesis and $g_{\mathrm{S}}$ depends on species and salinity level. For example, Ziziphus nummularia had greater reduction in photosynthesis and $g_{\mathrm{S}}$ than $Z$. rotundifolia (Meena et al., 2003). For salt-sensitive green ash (Fraxinus pennsylvanica), both $g_{\mathrm{S}}$ and net photosynthesis decreased significantly when the seedlings were subjected to salt stress ranging from seawater concentration to onetenth the concentration of seawater (Pezeshki and Chambers, 1986). Conversely, for halophyte Salvadora persica, net photosynthesis, $g_{\mathrm{S}}$, and transpiration rate were not reduced by salinity stress at $200 \mathrm{~mm} \mathrm{NaCl}$ compared with the control without $\mathrm{NaCl}$ (Maggio et al., 2000). Net photosynthesis, $g_{\mathrm{S}}$, and transpiration rates of Phillyrea latifolia grown at various salinity concentrations were markedly decreased and the differences of these rates between the control and salinity treatments became larger over time (Tattini et al., 2002). Summarizing this, the effect of salinity on leaf gas exchange depends on many factors such as leaf age, the level of salinity, and duration of salinity stress exposure in addition to species and genotype.

Chlorophyll fluorescence and chlorophyll content ( $S P A D$ reading). Chlorophyll fluorescence has been proved to be useful in salinity tolerance evaluation. The maximal photochemical efficiency of photosystem II (PSII), the ratio of variable fluorescence $\left(\mathrm{F}_{\mathrm{v}}\right)$ to maximal fluorescence $\left(\mathrm{F}_{\mathrm{m}}\right), \mathrm{F}_{\mathrm{v}} / \mathrm{F}_{\mathrm{m}}$, is commonly measured to examine damage in the photosynthetic apparatus caused by salinity stress (Jimenez et al., 1997; Percival, 2005; Percival and Fraser, 2001; Sixto et al., 2006). Percival (2005) concluded that measuring chlorophyll fluorescence $\left(\mathrm{F}_{\mathrm{v}} / \mathrm{F}_{\mathrm{m}}\right)$ of excised, salt-treated leaves under laboratory conditions can be used to evaluate salt tolerance without destroying whole plants. In our studies, we found that $\mathrm{F}_{\mathrm{v}} / \mathrm{F}_{\mathrm{m}}$ was reduced by elevated salinities at 3.0 and $6.0 \mathrm{dS} \cdot \mathrm{m}^{-1}$ in three rose rootstocks, but the reduction was small (Niu et al., 2008). The advantages of using chlorophyll fluorescence include the fact that fluorescence measurements use a light portable piece of equipment, and measurements are non-destructive and non-invasive. The effectiveness depends on species and salinity levels. For example, no differences were found in $\mathrm{F}_{\mathrm{v}} / \mathrm{F}_{\mathrm{m}}$ in tomato leaves treated with salinity up to $200 \mathrm{~mm} \mathrm{NaCl}$ in dark-adapted leaves (Zribi et al., 2009). However, the PSII photochemistry was modified in salt-affected plants in lightadapted leaves. Naumann et al. (2008) also reported that significant differences in lightadapted fluorescence yield were observed by Day 3 in Myrica cerifera plants treated with salinity stress, whereas the dark-adapted fluorescence yield did not show differences between the salinity treatment and control until Day 12, which was well after visible signs (Day 5) of stress were apparent

Salt stress not only causes leaf scorching and necrosis, but chlorosis as well, because it has been shown that low to moderate salinity stimulates chlorophyll degradation, whereas higher salt concentrations more drastically affect chlorophyll synthesis (Santos, 2004). Leaf chlorophyll concentration could be determined routinely, but destructively, by chemical analyses. The development of nondestructive handheld chlorophyll meters provides for the rapid measurement of a relative index of chlorophyll content, also called a leaf greenness index (Monje and Bugbee, 1992), and thus chlorosis. The most common 
chlorophyll meter, Minolta SPAD-502, provides a relative value of chlorophyll content, called a SPAD reading (SPAD, an acronym of Soil and Plant Analyzer Development; Minolta Camera Co., Osaka, Japan). By measuring the light transmission at the wavelengths of 650 and $940 \mathrm{~nm}$, a SPAD value ranging from 0 to 100 is generated to estimate leaf chlorophyll concentration (Markwell et al., 1995). These readings may be used as another parameter to screen differences in salt tolerance of multiple species or genotypes non-destructively. In a number of herbaceous and woody landscape plants, we found that less salt-tolerant species had either reduced SPAD readings or were significantly reduced with increasing salinity stress (Cabrera, 2003, 2009; Niu et al., 2007a).

\section{ADDITIONAL SOURCES OF INFORMATION}

The Southern California Salinity Coalition and National Water Research Institute maintains a web site with comprehensive literature review information related to salinity management guidelines for landscapes irrigated with recycled water (reclaimed water) (Tanji et al., 2008). This web site provides a broad range of information, including water quality of recycled water, management of root zone salinity, plant selection, and irrigation system. Wu and Dodge (2005) compiled salt tolerance information in tables based on the degree of salt tolerance for over 200 species of trees and palms, shrubs, and groundcovers. This information was developed based on a series of experiments conducted in California, which is a useful guide for plant selection. Grattan and Grieve (1999) reviewed comprehensively on the relations between salinity and mineral nutrition of horticultural crops and addressed the nutrients individually. The U.S. Salinity Laboratory has an updated version of a comprehensive bibliography on response of plants to salinity (http://www.ars.usda.gov/services/docs.htm? docid=8908), which is open access to the public according to Grieve et al. (2008).

\section{SUMMARY}

Salt tolerance of landscape plants varies widely with species, environmental conditions, and soil or substrate. Landscape plants, most of which are non-halophyte, have similar mechanisms of salt tolerance to agricultural crops. Elevated salinity in irrigation water reduces plant size and growth, causes foliar injury (reducing aesthetic value), and increases soil salinity. Assessment of salt tolerance for landscape plants should be based primarily on aesthetic value. As a result of the potential for significant salt accumulation, site assessment will be necessary to ensure good drainage when poor-quality water is used. Applying sufficient volumes of water to allow for adequate salt leaching and blending with less saline water can alleviate salt accumulation and sustain the prolonged use of alternative water sources for the irrigation of landscapes.

\section{Literature Cited}

Mazher, A.M., E.M. Fatma El-Questni, and M.M Farahat. 2007. Responses of ornamental plants and woody trees to salinity. World J. Ag. Sci. 3: 386-395.

Bernstein, L., L.E. Francois, and R.A. Clark. 1972. Salt tolerance of ornamental shrubs and ground covers. J. Amer. Soc. Hort. Sci. 97:550-556.

Bernstein, N., B.T. Asher, F. Haya, S. Pini, R. Ilona, C. Amram, and I. Marina. 2006. Application of treated wastewater for cultivation of roses (Rosa hybrida) in soil-less culture. Sci. Hort. 108:185-193.

Boland, A.M. 2008. Management of saline and/or recycled water for irrigated horticulture. Acta Hort. 792:123-134.

Cabrera, R.I. 2003. Growth, quality and nutrient responses of azalea hybrids to salinity. Acta Hort. 609:241-245.

Cabrera, R.I. 2009. Revisiting the salt tolerance of crape myrtles (Lagerstroemia spp.). Arboric. Urban Fores. 35:129-134.

Carter, C.T. and C.M. Grieve. 2006. Salt tolerance of floriculture crops, p. 279-287. In: Khan, M.A. and D.J. Weber (eds.). Ecophysiology of high salinity tolerant plants. Springer, Dordrecht, The Netherlands.

Cassaniti, C., C. Leonardi, and T.J. Flowers. 2009. The effects of sodium chloride on ornamental shrubs. Sci. Hort. 122:586-593.

Devitt, D.A., R.L. Morris, and L.K. Fenstermaker. 2005. Foliar damage, spectral reflectance, and tissue ion concentrations of trees sprinkle irrigated with waters of similar salinity but different chemical composition. HortScience 40:819-826.

Dobrowolski, J., M. O'Neill, L. Duriancik and J. Throwe (eds.). 2008. Opportunities and challenges in agricultural water reuse: Final report. USDA-CSREES.

Duncan, R.R., R.N. Carrow, and M.T. Huck. 2009. Turfgrass and landscape irrigation water quality: Assessment and management. CRC Press, Boca Raton, FL.

Eom, S.H., T.L. Setter, A. DiTommaso, and L.A Weston. 2007. Differential growth response to salt stress among selected ornamentals. J. Plant Nutr. 30:1109-1126.

Farnham, D.S., R.F. Hasek, and J.L. Paul. 1985. Water quality: Its effects on ornamental plants. University of California Cooperative Extension Leaflet No. 2995.

Fostad, O. and P.A. Pedersen. 2000. Containergrown tree seedling responses to sodium chloride applications in different substrates. Environ. Pollut. 109:203-210.

Fox, L.J., J.N. Grose, B.L. Appleton, and S.J. Donohue. 2005. Evaluation of treated effluent as an irrigation source for landscape plants. J. Env. Hort. 23:174-178.

Grattan, S.R. and C.M. Grieve. 1999. Salinitymineral nutrient relations in horticultural crops. Sci. Hort. 78:127-157.

Grieve, C., L. Wu, L. Rollins, and A. Harivandi. 2008. Tolerance by landscape plants of salinity and of specific ions (Chapter V). In: A comprehensive literature review on salt management guide for landscape irrigation with recycled water in coastal southern California, Dec. 2009. $<$ http://www.salinitymanagement.org $>$.

James, R.A., A.R. Rivelli, R. Munns, and S. von Caemmerer. 2002. Factors affecting $\mathrm{CO}_{2}$ assimilation, leaf injury and growth in salt-stressed durum wheat. Funct. Plant Biol. 29:1393-1403.

Jimenez, M.S., A.M. Gonzalez-Rodriguez, D. Morales, M.C. Cid, A.R. Socorro, and M. Caballero. 1997. Evaluation of chlorophyll fluorescence as a tool for salt stress detection in roses. Photosynthetica 33:291-301.
Kjelgren, R., L. Rupp, and D. Kilgren. 2000. Water conservation in urban landscapes. HortScience 35:1037-1040.

Maas, E.V. 1990. Crop salt tolerance, p. 262-304. In: Tanji, K.K. (ed.). Agricultural salinity assessment and management. Amer. Soc. of Civil Engineers, ASCE Manuals and reports on engineering practice No. 71, New York, NY.

Maggio, A., M.P. Reddy, and R.J. Joly. 2000. Leaf gas exchange and solute accumulation in the halophyte Salvadora persica grown at moderate salinity. Environ. Exp. Bot. 44:31-38.

Markwell, J.M., J.C. Osterman, and J.L. Mitchell. 1995. Calibration of the Minolta SPAD-505 leaf chlorophyll meter. Photosynth. Res. 46: $467-472$.

Marosz, A. 2004. Effects of soil salinity on nutrient uptake, growth, and decorative value of four ground cover shrubs. J. Plant Nutr. 27:977-989.

Marschner, H. 1995. Mineral nutrition of higher plants. 2nd Ed. Academic Press, San Diego, CA.

Meena, S.K., N.K. Gupta, S. Gupta, S.K. Khandelwal, and E.V.D. Sastry. 2003. Effect of sodium chloride on the growth and gas exchange of young Ziziphus seedling rootstocks. J. Hortic. Sci. Biotechnol. 78:454-457.

Monje, O.A. and B. Bugbee. 1992. Inherent limitations of nondestructive chlorophyll meter: A comparison of two types of meters. HortScience 271:69-71.

Morgan, K.T., T.A. Wheaton, L.R. Parsons, and W.S. Castle. 2008. Effects of reclaimed municipal waste water on horticultural characteristics, fruit quality, and soil and leaf mineral concentration of citrus. HortScience 43:459-464.

Munns, R. 2002. Comparative physiology of salt and water stress. Plant Cell Environ. 25:239-250.

Munns, R. and M. Tester. 2008. Mechanisms of salinity tolerance. Annu. Rev. Plant Biol. 59:651681.

Naumann, J.C., D.R. Young, and J.E. Anderson. 2008. Leaf chlorophyll fluorescence, reflectance, and physiological response to freshwater and saltwater flooding in the evergreen shrub, $M y r$ ica cerifera. Environ. Exp. Bot. 63:402-409.

Niu, G. and D.S. Rodriguez. 2006a. Relative salt tolerance of five herbaceous perennials. HortScience 41:1493-1497.

Niu, G. and D.S. Rodriguez. 2006b. Relative salt tolerance of selected herbaceous perennials and groundcovers. Sci. Hort. 110:352-358.

Niu, G. and D.S. Rodriguez. 2008. Responses of growth and ion uptake of four rose rootstocks to chloride- or sulfate-dominated salinity. J. Amer. Soc. Hort. Sci. 133:663-669.

Niu, G., D.S. Rodriguez, and L. Aguiniga. 2007a. Growth and landscape performance of ten herbaceous species in response to saline water irrigation. J. Env. Hort. 25:204-210.

Niu, G., D.S. Rodriguez, and Y.T. Wang. $2007 \mathrm{~b}$. Salinity and growing medium regulate growth, morphology and ion uptake of Gaillardia aristata. J. Env. Hort. 25:89-94.

Niu, G., D.S. Rodriguez, and L. Aguiniga. 2008. Effect of saline water irrigation on growth and physiological responses of three rose rootstocks. HortScience 43:1479-1484.

Pasternak, D. and Y.D. Malach. 1994. Crop irrigation with saline water, p. 599-622. In: Pessarakli, M.O. (ed.). Handbook of plant and crop stress. Marcel Dekker, New York, NY.

Percival, G.C. 2005. Identification of foliar salt tolerance of woody perennials using chlorophyll fluorescence. HortScience 40:1892-1897.

Percival, G.C. and G.A. Fraser. 2001. Measurement of the salinity and freezing tolerance of Crataegus genotypes using chlorophyll fluorescence. J. Arbor. 27:233-245. 
Pezeshki, S.R. and J.L. Chambers. 1986. Effect of soil salinity on stomatal conductance and photosynthesis of green ash (Fraxinus pennsylvanica). Can. J. For. Res. 16:569-573.

Qian, Y.L., J.M. Fu, J. Klett, and S.E. Newman. 2005. Effects of long-term recycled wastewater irrigation on visual quality and ion concentrations of ponderosa pine. J. Environ. Hort. 23:185-189.

Quist, T.M. and C.F. Williams. 1999. Irrigation water quality and ion balance in leaves of deciduous ornamental trees. J. Plant Nutr. 22: 1011-1019.

Safi, M.I., A. Fardous, M. Muddaber, S. Ei-Zuraiqi, A. Balaweneh, L. Al-Hadidi, and I. Bashabsheh. 2007. Long term effects of reclaimed water on rose and carnation cut flower crops in soil and soilless media. Journal of Applied Sciences 7:1191-1198.

Santos, C.V. 2004. Regulation of chlorophyll biosynthesis and degradation by salt stress in sunflower leaves. Sci. Hort. 103:93-99.

Schuch, U. 2005. Effect of reclaimed water and drought on salt-sensitive perennials. HortScience 40:1095 (Abstract).
Shannon, M.C., C.M. Grieve, and L.E. Francois. 1994. Whole-plant response to salinity, p. 199244. In: Wilkinson, R.E. (ed.). Plant environment interaction. Marcel Dekker, New York, NY.

Sixto, H., I. Aranda, and J.M. Grau. 2006. Assessment of salt tolerance in Populus alba clones using chlorophyll fluorescence. Photsynthetica 44:169-173.

Tanji, K., S. Grattan, C. Grieve, A. Harivandi, L. Rollins, D. Shaw, B. Sheikh, and L. Wu. 2008. A comprehensive literature review on salt management guide for landscape irrigation with recycled water in coastal southern California. Dec. 2009. <http://www.salinitymanagement.org>.

Tanji, K.K. 2002. Salinity in the soil environment, p. 21-51. In: Läuchli, A. and U. Lüttge (eds.). Salinity: Environment-plants-molecules. Kluwer Academic Publishers, Dordrecht, The Netherlands.

Tanwar, B.S. 2003. Saline water management for irrigation (3rd revised draft). Work Team on Use of Poor Quality Water for Irrigation (WTPQW), International Commission on Irrigation and Drainage (ICID), New Delhi, India.
Tattini, M., G. Montagni, and M.L. Traversi. 2002. Gas exchange, water relations and osmotic adjustment in Phillyrea latifolia grown at various salinity concentrations. Tree Physiol. 22:403-412.

Wahome, P.K. 2003. Mechanisms of salt $(\mathrm{NaCl})$ stress tolerance in horticultural crops-A mini review. Acta Hort. 609:127-131.

Wu, L. and L. Dodge. 2005. A special report for the Elvenia J. Slosson Endowment Fund: Landscape salt tolerance selection guide for recycled water irrigation. University of California, Davis, CA.

Wu, L., X. Guo, and A. Harivandi. 2001. Salt tolerance and salt accumulation of landscape plants irrigated by sprinkler and drip irrigation systems. J. Plant Nutr. 24:1473-1490.

Zollinger, N., R. Koenig, T. Cerny-Koenig, and R. Kjelgren. 2007. Relative salinity tolerance of intermountain western United States native herbaceous perennials. HortScience 42:529-534.

Zribi, L., G. Fatma, R. Fatma, R. Salwa, N. Hassan, and R. Mohamed Néjib. 2009. Application of chlorophyll fluorescence for the diagnosis of salt stress in tomato (Solanum lycopersicum, variety Rio Grande). Sci. Hort. 120:367-372. 